\title{
DINÂMICA SEDIMENTAR DO CANAL DA GALHETA, VIA DE ACESSO AO PORTO DE PARANAGUÁ MARCELO RENATO LAMOUR*
}

\author{
DISSERTAÇÃO DE MESTRADO - Programa de Pós-Graduação em Geologia - UFPR \\ DATA DE DEFESA: 1 set. 2000
}

\begin{abstract}
A baía de Paranaguá está localizada no litoral centro-norte do Paraná. Três canais naturais denominados Norte e Sueste dão acesso ao oceano Atlântico, ao norte da llha do Mel, e da Galheta ao sul da mesma ilha. Este último é a principal via de acesso ao porto de Paranaguá. Para que sejam mantidas profundidades seguras de navegação, é necessário que sejam feitas dragagens periódicas. Os objetivos principais deste trabalho foram o de caracterizar os sedimentos de fundo do canal e suas adjacências entre 1972 e 1998; acompanhar as variações morfológicas que ocorreram na superfície de fundo; quantificar taxas de sedimentação para os trechos com assoreamento crítico e compreender os processos que transportam os sedimentos na desembocadura, sul da baía. Os sedimentos do canal da Galheta são compostos predominantemente por areias finas, moderadamente a bem selecionadas, com assimetria muito negativa, sendo leptocúrticas no setor externo, e extremamente leptocúrticas a muito leptocúrticas no setor
\end{abstract}

interno. A direção preferencial de chegadas de ondas é do quadrante SE e a deriva longitudinal no sentido NE. O fluxo sedimentar que se desloca ao longo do litoral paranaense divide-se em dois fluxos principais: 1) no setor externo um, contorna o lobo terminal do delta de vazante, flexionando o eixo navegável do canal com uma frente de avanço preferencial. Apesar das tentativas de retificação deste eixo, pelas dragagens, uma curvatura persistiu ao longo das décadas; 2) no setor interno o fluxo sedimentar adentra o estuário, seguindo próximo à margem do balneário Pontal do Sul, sendo redirecionado pelas correntes de vazante provindas do canal da Cotinga, para o canal da Galheta. Com a perda de energia das correntes de maré, no trecho mais largo do estuário, os sedimentos depositam-se formando o banco interno. As taxas de sedimentação obtidas para o setor externo e interno variaram em torno de $20.000 \mathrm{~m}^{3} / \mathrm{mês}$, sendo necessário um maior conjunto de dados, para a confirmação de um possível padrão de assoreamento no canal. 